\title{
The Impact of Transparency Ratio on Thermal Comfort: A Field Study on Educational Building
}

\author{
Fatma Zoroğlu Çağlar ${ }^{1, *}$, Gülay Zorer Gedik ${ }^{1}$, Hüseyin Gökdemir ${ }^{2}$ \\ ${ }^{1}$ Faculty of Architecture, Yıldız Technical University, Istanbul, Turkey \\ ${ }^{2}$ R\&D Center, Çuhadaroğlu Metal San. Paz. A.Ş, Istanbul, Turkey
}

Received July 22, 2020; Revised August 12, 2020; Accepted August 20, 2020

\begin{abstract}
Cite This Paper in the following Citation Styles
(a): [1] Fatma Zoroğlu Çağlar, Gülay Zorer Gedik, Hüseyin Gökdemir, "The Impact of Transparency Ratio on Thermal Comfort: A Field Study on Educational Building," Civil Engineering and Architecture, Vol. 8, No. 5, pp. 890 - 897, 2020. DOI: 10.13189/cea.2020.080516.
\end{abstract}

(b): Fatma Zoroğlu Çağlar, Gülay Zorer Gedik, Hüseyin Gökdemir (2020). The Impact of Transparency Ratio on Thermal Comfort: A Field Study on Educational Building. Civil Engineering and Architecture, 8(5), 890 - 897. DOI: 10.13189/cea.2020.080516.

Copyright $\bigcirc 2020$ by authors, all rights reserved. Authors agree that this article remains permanently open access under the terms of the Creative Commons Attribution License 4.0 International License

\begin{abstract}
The thermal comfort conditions of the educational buildings affect students' attention, focus, perception and learning levels. The design of transparent areas is important in the control of solar radiation affecting thermal comfort conditions. The aim of this study is to determine thermal comfort conditions in classrooms with different transparency ratios and to make suggestions for improvements. Classrooms in the same building on the university campus, in the same direction (south) and with different transparency ratios were determined as study areas. Measurements (PMV-PPD) and surveys (AMV-APD) were carried out during a day in heating period. The thermal comfort conditions were evaluated according to the comfort intervals specified in ASHRAE-55 and ISO-7730 standards. The results showed that there were significant differences in thermal comfort between classrooms. If the transparency ratio is more than necessary, it causes discomfort and redundant energy consumption. Suggestions have been made to ensure solar control and thermal comfort conditions.
\end{abstract}

Keywords Transparency Ratio, Thermal Comfort, PMV-PPD, AMV-APD, Classrooms

\section{Introduction}

Solar gains contribute to the cooling load and increase energy consumption in summer [1]; on the other hand, they have a positive effect in winter. Transparent areas are the most effective building envelope components in solar gains. The design of transparent areas (transparency ratio, transmission coefficient and use of solar control devices) is important for the control of solar gains.

Short wavelengths of solar radiation passing through the glass turn into long waves as a result of contact with the surfaces in the interior and long wavelengths cannot pass through the glass. As a result of these event, a greenhouse effect occurs and indoor temperature increases. In particular, glazed facades facing south or west (in the northern hemisphere) are particularly vulnerable to overheating, inducing thermal discomfort [2]. Large glazing areas are typical of newly constructed buildings. Solar radiation passes through the glass, warming the environment and causing thermal discomfort especially in large glazed facade buildings. An appropriate transparency ratio improves thermal comfort by controlling solar energy gain and reduces energy consumption.

Thermal discomfort negatively affects students' learning performance [3]. Providing good environmental conditions for educational buildings is important because of the negative influence of thermal discomfort on students' and teachers' learning/teaching performance and health. Their health and wellbeing depend on an appropriate educational environment $[4,5]$.

According to Turkish Higher Education Council, University students and academics constitute about $9.8 \%$ of the population and there were 207 University campuses in Turkey. Students and academicians of 61 universities in 
Istanbul constitute $26.3 \%$ of this rate [6]. Students and academicians have a significant share in the population and spend most of their time in university buildings. Therefore, appropriate thermal comfort conditions are of great importance for those users.

The influence of the properties of the transparent component on the thermal comfort has been investigated in several studies [1,7-11].

Although there have been a lot of researches in the transparency ratio and thermal comfort, there are few studies on the evaluation of existing educational buildings with the field studies. This study aims to determine that the thermal comfort conditions depending on the transparency ratio (WWR - Window to Wall Ratio) are different in the existing educational building and to make suggestions for improvement. The thermal comfort conditions in the university classrooms with different transparency ratios were determined by the objective (measurement) and subjective (survey) methods. PMV (Predicted Mean Vote) and PPD (Predicted Percentage of Dissatisfied) values obtained as a result of the measurements and AMV (Actual Mean Vote) and APD (Actual Percentage of Dissatisfied) values obtained as a result of the surveys were evaluated according to ASHRAE-55 and ISO 7730 standards. As a result, it was determined that there were significant differences in thermal comfort between classrooms. If the transparency ratio is more than necessary, it causes discomfort and redundant energy consumption. Suggestions have been made to improve the thermal comfort of the existing educational buildings depending on the transparency ratio and to reduce energy consumption. If integrated with other similar works, these results can be exploited to design of transparent areas of existing or in design phase educational building.

\section{Method}

It was decided to conduct field studies in an existing educational building in Istanbul (temperate-humid climate) on transparency ratio (WWR - Window to Wall Ratio) and thermal comfort as a result of the literature studies. Classrooms are determined as study areas in the same building (on the 4th and 5 floors) on the university campus, in the same direction (south) and with different transparency ratios (other properties of the volume are the same). Measurements (objective method) and surveys (subjective method) were carried out at the same time during a day in the heating period. While the field study was conducted, the heating system was completely off at all the rooms. The measurements were performed with Testo 480 - Digital Temperature and Humidity Meter. The survey results were analyzed using SPSS 22 (Statistical Package for the Social Sciences). PMV-PPD and AMV-APD data were obtained as a result of measurements and surveys, respectively. Results were evaluated according to ASHRAE 55 and ISO 7730 standards with table and graphic methods. Suggestions were presented for determining and improving thermal comfort conditions in classrooms with different transparency ratios.

\subsection{Transparency Ratio on Thermal Comfort}

The satisfaction of an individual with the thermal environment is defined as thermal comfort [12]. When a building is designed by evaluating outdoor climatic conditions, indoor thermal comfort can be achieved with less energy consumption. Outdoor climate conditions depend on factors such as air temperature, solar radiation, humidity, and air velocity. Indoor thermal comfort depends on objective and subjective parameters. Objective parameters are determined as indoor air temperature, mean radiant temperature, relative humidity, air velocity, activity level, and clothing insulation level. Subjective parameters are factors that vary individually and can be listed as age, gender, weight (subcutaneous fat), and health status etc. [13]. One of the most effective outdoor climate conditions in thermal comfort is solar radiation. The heating of the indoor environment with solar gains is very fast and effective especially in buildings with large transparent areas because of the occurring greenhouse effect.

Transparent areas are thin, impermeable surface and they have a high U value and low time delay, compared with opaque areas. For this reason, the transparent areas have the fastest and most effective heat gain-loss and condensation in the building envelope. The design of transparent areas is very important in terms of its effect on thermal comfort. This study focused mainly on determining the effect of solar radiation gain provided through transparent areas on thermal comfort.

\section{Determination of the Field Study Conditions}

Thermal comfort conditions play an important role in efficiency and health in educational buildings. Istanbul is the province with the highest number of universities, students and academicians in Turkey. İstanbul has a temperate-humid climate. The existing educational building to be studied has been selected at a university campus in Istanbul.

The southern facade is the most effective facade in solar gains. For this reason, classrooms with transparent areas on the south side have been determined. Since thermal comfort depends on many factors, the other properties of the classrooms (environmental conditions, orientation, room dimensions, height above sea level, the building envelope properties, the material properties, etc.) are as similar as possible.

The field study was conducted on Yildız Technical 
University, B block, classrooms B-502, B-503, B-402 and B-403 (Fig 1.). The classrooms are on the 4th and 5th floors. There is no obstacle that prevents daylighting from the south in the classrooms. The properties of the classrooms are given in table 1.

The building envelope (opaque and transparent components) material properties ( $\mathrm{U}$ value, $\mathrm{g}$ value etc.) of the determined classrooms are the same. The $\mathrm{U}$ value of glass determined as $1,84 \mathrm{~W} / \mathrm{m}^{2} \mathrm{~K}$ and the U-value of the exterior wall determined as $0,38 \mathrm{~W} / \mathrm{m}^{2} \mathrm{~K}$ by measurement with Testo 635-2. Transparency ratios (WWR - Window to Wall Ratio) of classrooms are given in table 2. The difference between the transparency ratios of the southern facades is quite large.

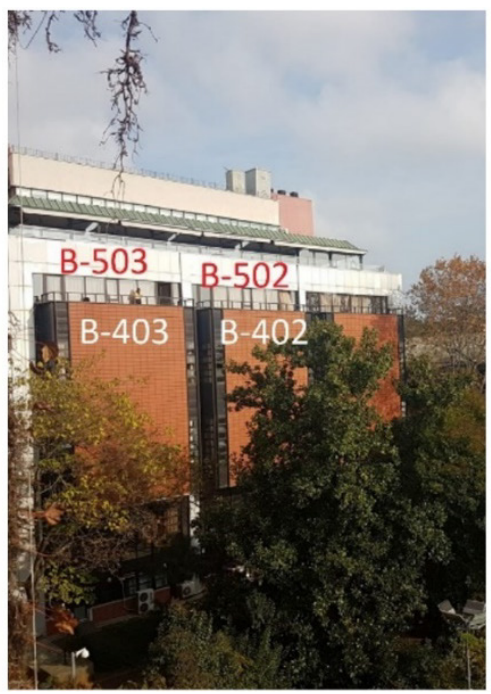

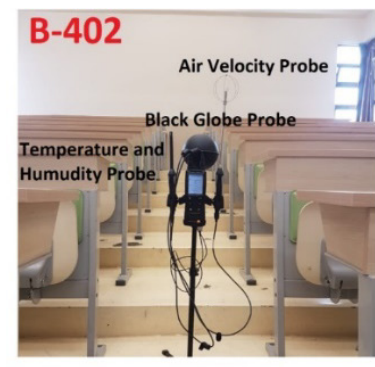

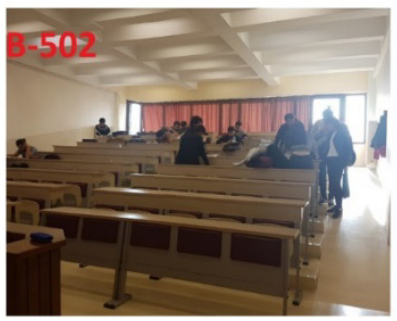

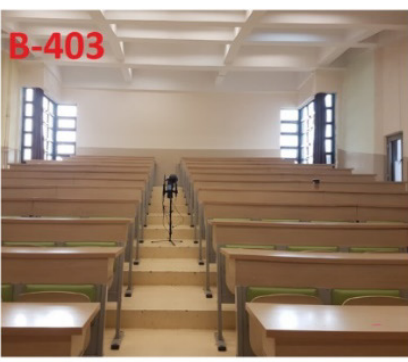

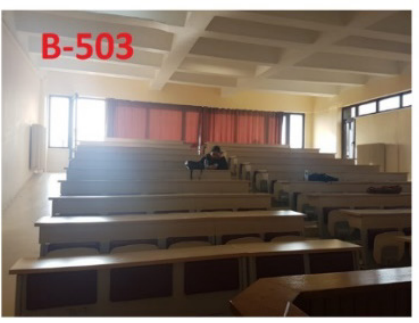

Figure 1. Exterior and interior of classrooms and measurement device (B-402)

Table 1. Properties of Classrooms

\begin{tabular}{cccc}
\hline Classrooms & $\begin{array}{c}\text { Direction of } \\
\text { classroom }\end{array}$ & Dimensions & Heating system and number of Radiator \\
\hline \multirow{2}{*}{ B 502 } & South & $\begin{array}{c}\text { Capacity } \\
\text { (person) }\end{array}$ \\
\hline \multirow{2}{*}{ B 503 } & South and West & $\begin{array}{c}11,76 \times 8,90 \times(2,7-3,80) \\
\text { Trapezoidal Prism } \\
\text { Trapezoidal Prism }\end{array}$ & $\begin{array}{c}\text { Gas central heating systems, Cast iron } \\
\text { radiator- } 3 \text { radiators }\end{array}$ \\
\hline \multirow{2}{*}{ B 402 } & South & $\begin{array}{c}13,26 \times 8,90 \times(2,7-3,80) \\
\text { Trapezoidal Prism }\end{array}$ & $\begin{array}{c}\text { Gas central heating systems, Cast iron } \\
\text { radiator- } 4 \text { radiators }\end{array}$ \\
\hline \multirow{2}{*}{ B 403 } & South and West & $\begin{array}{c}13,26 \times 9,08 \times(2,7-3,80) \\
\text { Trapezoidal Prism }\end{array}$ & $\begin{array}{c}\text { Gas central heating systems, Cast iron } \\
\text { radiator- 3 radiators } \\
\text { radiator- } 4 \text { radiators }\end{array}$ \\
\hline
\end{tabular}

Table 2. Properties of transparent component

\begin{tabular}{|c|c|c|c|c|}
\hline \multirow{2}{*}{ Classrooms } & \multirow{2}{*}{$\begin{array}{l}\text { Direction of transparent } \\
\text { component }\end{array}$} & \multicolumn{3}{|c|}{$\begin{array}{c}\text { Transparency ratio } \\
\text { (WWR - Window to Wall Ratio) }\end{array}$} \\
\hline & & South & West & East \\
\hline B 502 & South & $\% 60$ & - & - \\
\hline В 503 & South and west & $\% 60$ & $\% 11,5$ & - \\
\hline В 402 & South, west and east & $\% 7,5$ & $\% 6$ & $\% 6$ \\
\hline В 403 & South, west and east & $\% 7,5$ & $\% 11,5$ & $\% 6$ \\
\hline
\end{tabular}




\subsection{Determination of the Outdoor Weather Conditions}

It is necessary to know the outdoor weather conditions affecting the thermal comfort of the indoor environments in order to make the correct assessment. Outdoor measurements were made on the measurement day, keeping the measurement parameters the same. Measurements were made in clear sky conditions, on sunny days and in an open area. Data on the outdoor weather conditions within the campus in Istanbul (which has a temperate humid climate) where the study is conducted is given in table 3 .

Table 3. Outdoor weather conditions of the field study days

\begin{tabular}{ccccc}
\hline Date & Time & $\begin{array}{c}\text { Air } \\
\text { Temperature } \\
\left({ }^{\circ} \mathbf{C}\right)\end{array}$ & $\begin{array}{c}\text { Relative } \\
\text { Humidity } \\
(\% \mathbf{r})\end{array}$ & $\begin{array}{c}\text { Air } \\
\text { Velocity } \\
(\mathbf{m} / \mathbf{s})\end{array}$ \\
\hline $\mathbf{2 0 . 1 2 . 1 9}$ & 15.50 & 15,2 & 68,7 & 1,4 \\
\hline
\end{tabular}

\subsection{Determination of the Thermal Comfort Conditions}

Thermal comfort may be determined with different methods. Most common practices are objective (measurement) and subjective (survey) methods. Both methods used in this study for comparing the results and determining the thermal comfort in the most accurate way.

Field studies were carried out in the heating period on 20.12.2019. The southern facade of the buildings in the 41st latitude (latitude of Istanbul) is exposed to direct sunlight between about 10.00-16.00 on the field study day. Therefore, field study hours are determined between 12.00 and 16.00 .

Measurement studies were conducted on four different unoccupied (no occupant) classrooms and were repeated while classroom B-502 was occupied (with occupant). In order to determine the effect of transparency ratio on thermal comfort, the most important points in the plan are the closest and farthest distance to the transparent area. Three points were determined in each classroom for measurements (Fig. 2). While the field study was conducted, the radiators (heating system) were completely closed, the curtains were open and the windows and doors were closed at all the rooms.

The measurements were performed with Testo 480 Digital Temperature and Humidity Meter (Fig. 1) [14]. This device gives the thermal comfort values as PMV and PPD according to the input data and the instantaneous values of the objective parameters. The required data for the measurements are determined according to the ISO 7730, ASHRAE 55 standards [12, 15], survey results and literature (Table 4). The clothing insulation level was determined as 0.7 clo according to the surveys. The activity level was determined as 1.2 met $[12,15]$ and the measurement height was determined as $1.1 \mathrm{~m}$ [12] according to the standards. The measurements were carried out for 5 minutes at 30-second intervals at each point after the device was installed and held 5 minutes.

Survey questions were prepared using the ISO 10551, ISO 7730 and ASHRAE 55 standard [12,15,16]. Clothing insulation levels (clo) were determined by observation-based table processing and calculation. The survey results were analyzed using SPSS 22 (Statistical Package for the Social Sciences). AMV and APD obtained from the question related to the seven-point thermal sensation scale in the survey.

In order to determine the thermal comfort, PMV - PPD and AMV - APD values are used. According to measurement and survey results, it is determined whether the environment is comfortable by comparing with the values given in ISO 7730 and ASHRAE 55 standards. Classification regarding the PMV and PPD values that describe the satisfaction state according to ASHRAE 55 and ISO 7730 Standards is given in Table $5[12,15]$.

$-0,5<\mathrm{PMV}<+0,5$ range is considered as comfortable according to ISO 7730 and ASHRAE 55 standards. This range means $10 \%$ PPD value $[12,15]$. The closer the PMV is to 0 , it means the more comfortable the environment. PMV obtained from measurements was evaluated according to this range. $-1<\mathrm{AMV}<+1$ range is considered as comfortable $[12,15]$. The closer the AMV is to 0 , it means the more comfortable the environment. AMV obtained from survey question which is related to seven-point thermal sensation scale was evaluated according to this range. 


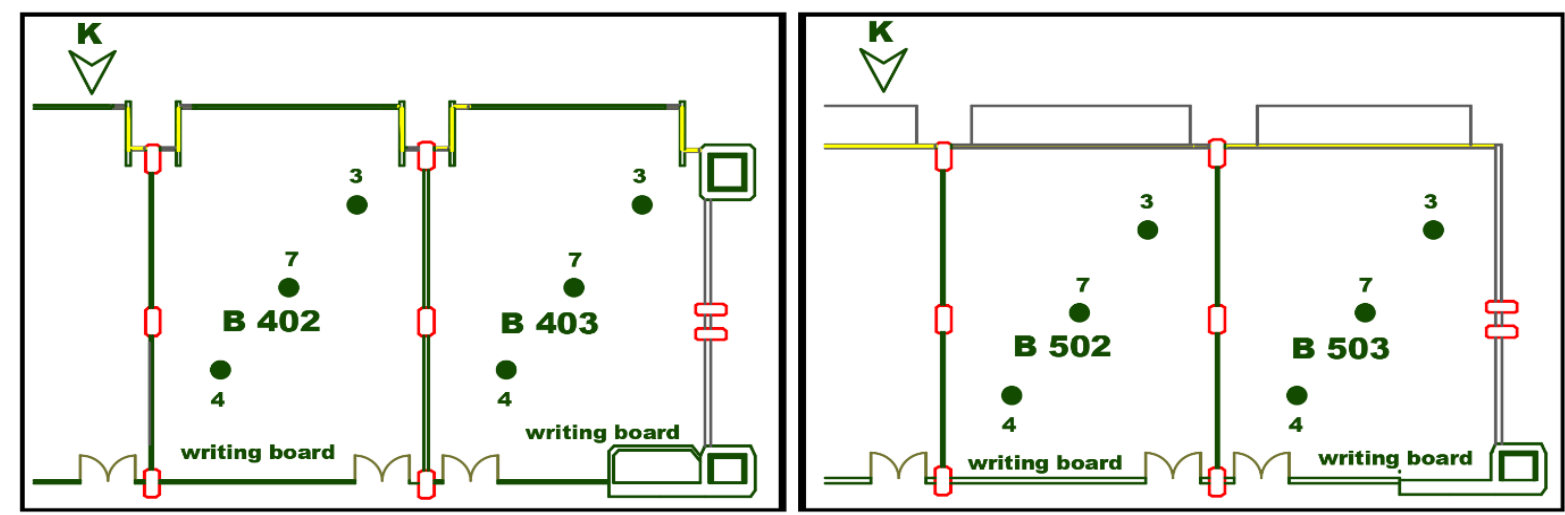

Figure 2. Plans and measurement points of classrooms

Table 4. Measurement conditions of the classrooms

\begin{tabular}{ccccc}
\hline $\begin{array}{c}\text { Point Number for } \\
\text { Each Classroom }\end{array}$ & $\begin{array}{c}\text { Measurement } \\
\text { Device Height }\end{array}$ & $\begin{array}{c}\text { Measurement } \\
\text { Type-Duration-Period }\end{array}$ & $\begin{array}{c}\text { Activity } \\
\text { Level }\end{array}$ & $\begin{array}{c}\text { Clothing Insulation } \\
\text { Level }\end{array}$ \\
\hline 3 point & 1,1 meter & According to time -5 min $-30 \mathrm{sec}$ & 1,2 met & $0,7 \mathrm{clo}$ \\
\hline
\end{tabular}

Table 5. Categories of thermal environment

\begin{tabular}{cccccc}
\hline \multirow{2}{*}{ Category } & \multicolumn{2}{c}{ ISO 7730 } & \multicolumn{2}{c}{ ASHRAE 55 } \\
\cline { 2 - 5 } & PPD & PMV & PPD & PMV \\
\hline A (I) & $6 \%$ & \pm 0.2 & $10 \%$ & \pm 0.5 \\
\hline B (II) & $10 \%$ & \pm 0.5 & $20 \%$ & \pm 0.85 \\
\hline C (III) & $15 \%$ & \pm 0.7 & - & - \\
\hline
\end{tabular}
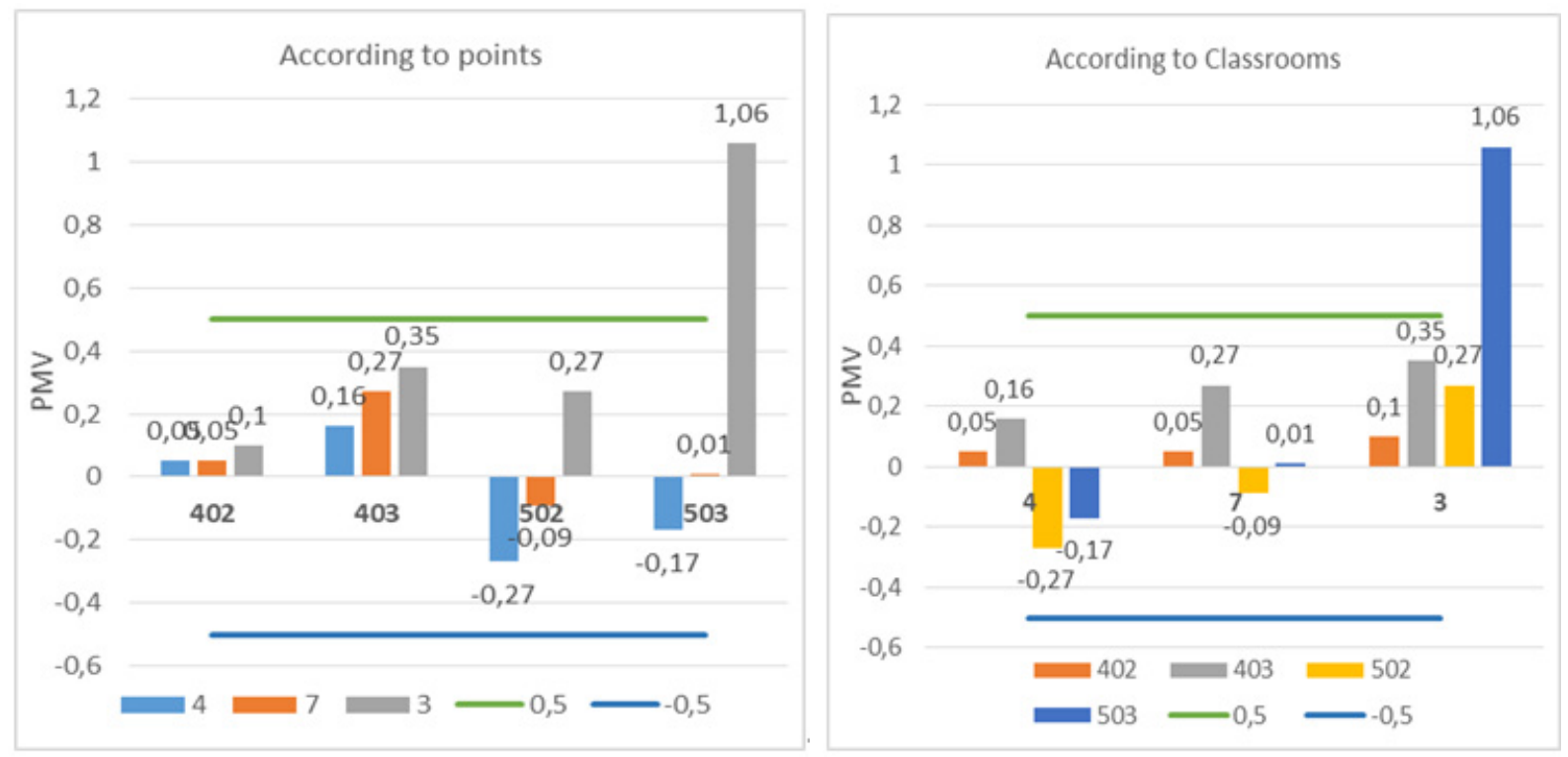

Figure 3. Measurement results in unoccupied classrooms 


\section{Results}

\subsection{Measurements Results}

The results of the field study were analysed by classrooms and points. Measurement results of classrooms B-402, B-403 and B-502, B-503 are given in Figure 3.

\section{Evaluation of thermal comfort in classrooms B-402 and B-403;}

- $\quad$ PMV is on the hot side and is within the comfort limits in both classrooms.

- The 3rd point is the most uncomfortable point in both classrooms.

- Classroom B-403 is more uncomfortable than classroom B-402 for all three points.

\section{Evaluation of thermal comfort in classrooms B-502 and B-503;}

- $\quad$ PMV is on the cold side at 4 th and 7 th points in classroom B-502, and at 4th point in classroom B-503.

- The 3rd point is uncomfortable on the hot side but PMV values of the other points are within the comfort limits in classroom B-503.

\section{Comparison of classrooms B-402, B-403 and B-502, B-503;}

- When the PMV values of the 3rd point are compared, it is determined that there are big differences between the classrooms B-402, B-502 and between classrooms B-403, B-503.

- While the PMV is within the comfort limits in the classrooms B-402, B-403, B-502, it is determined that the comfort limits mostly exceeded on the hot side on the 3rd point in the classroom B-503.

- $\quad$ The difference in PMV values between 4th, 7th points and 3rd point in classrooms B-502 and B-503 are quite large. However, PMV values between points in classrooms B-402 and B-403 are closer to each other.

- The PMV values are cold side in points far from the window in classrooms B-502 and B-503. However, the PMV values are hot side at all points in classrooms B-402 and B-403.

\section{Evaluation of thermal comfort of unoccupied (no occupant) and occupied (with occupant) classroom;}

Measurement studies were conducted on both unoccupied (no occupant) and occupied (with occupant) classroom B-502 conditions. When measurements were made, there were 70 people in the classroom B-502. Measurement results of occupied and unoccupied classroom B-502 are given in Figure 4.

- When there is no occupant in the classroom, PMV is within the comfort limits. When occupants are in the classroom PMV is on the hot side in all three points and outside the comfort limits in the 3rd and 4th points.

- When occupants are in the classroom (70 people), PMV increases at all three points on the hot side. The increase on the hot side is the most at the 3rd point.

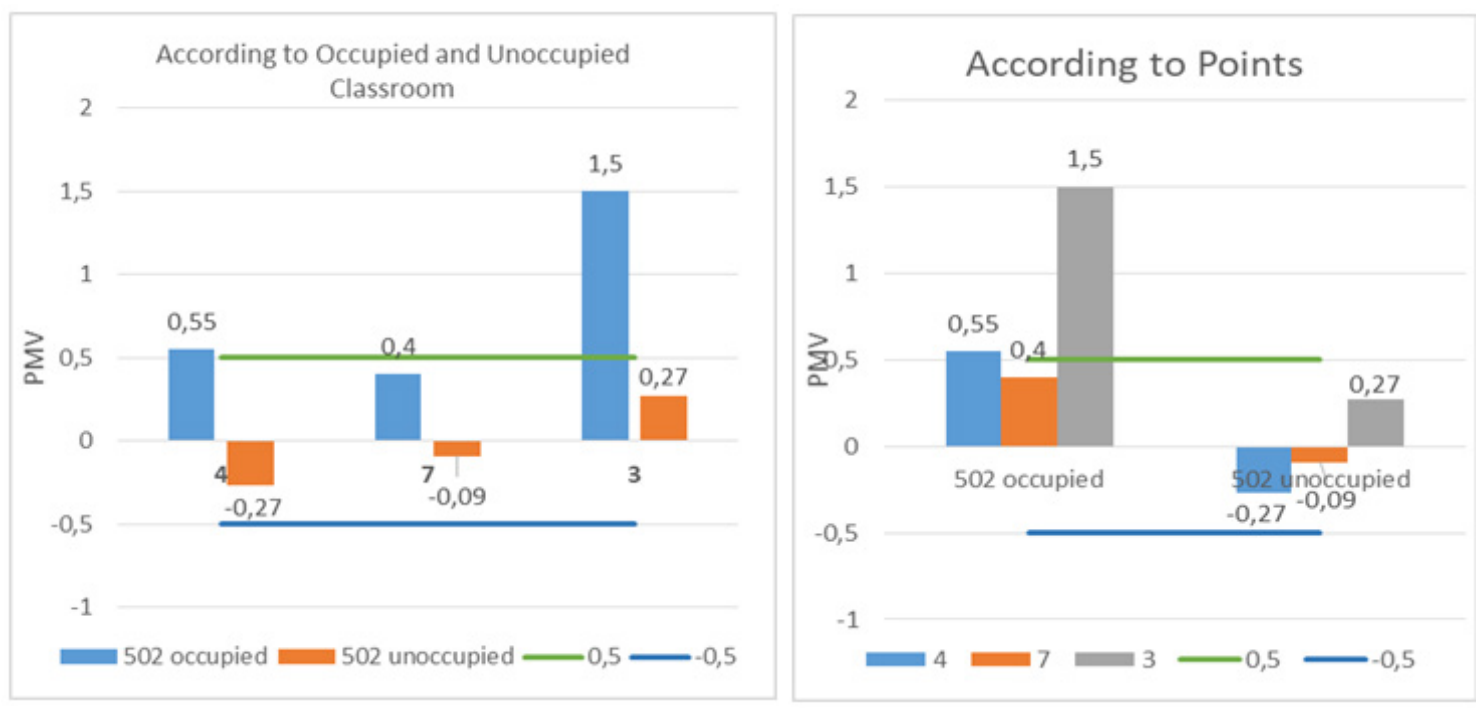

Figure 4. Measurement results in occupied and unoccupied classroom B-502 


\subsection{Survey Results}

In order to obtain reliable and accurate results, it is necessary to determine the clothing insulation levels before the measurements [17]. Therefore, a detailed table has been created to determine the clothing insulation level before measurements. The mean clothing insulation level of 62 students was determined to be 0.73 clo with 2-day observation-based table processing and calculation in front of the classrooms in the study area.

The planned process for conducting surveys could not be completed because the international negative situation arose and the universities continue their education with remote access in the spring period of 2019-2020. For this reason, the study could not be repeated and the data of the surveys conducted with few students were shared.

The surveys including questions about thermal comfort were made in classroom B-503 and 11 undergraduate students (6 males and 5 females) participated. It was determined that $54.5 \%$ of the students sat at the 4 th point during the lesson. $90.9 \%$ of the students stated that their time in the classroom was more than 30 minutes. $54.5 \%$ of the occupants stated that sense of thermal comfort is neutral. AMV value is 0,18 and APD value is 9,1 according to survey results. $-1<\mathrm{AMV}<+1$ range is considered as comfortable according to ISO 7730 and ASHRAE 55 standards. Occupants have felt neutral according to AMV and APD values.

\section{Discussion and Conclusions}

Occupants' satisfaction in terms of thermal comfort is important to increase efficiency in educational buildings which students and academicians are the main users. It was determined that the effect of transparency ratio on thermal comfort is quite high in the existing educational building. As a result of the field study, it is determined that the classrooms with low transparency ratio are more comfortable. The high transparency ratio caused classrooms to overheat and uncomfortable.

- The PMV value of the point close to the window was higher than the other points because of solar radiation.

- The difference between PMV values of points close to the window and far from the window is quite high in classrooms with a high transparency ratio.

- There are not many differences in thermal comfort between the points in the classrooms with a low transparency ratio.

- It was determined that PMV values increased on the hot side while the classroom B-502 was occupied. When the classroom was unoccupied, the PMV values were within the comfort limits, while the classroom was occupied, the PMV values exceeded the comfort limits at some points. The highest increase in PMV values was the point close to the window when the classroom was occupied and this difference was quite high.

- As a result of surveys, occupants felt neutral according to AMV and APD values. The majority of users stated that they were sitting at the 4th point during the lesson, which was also comfortable in the measurement results.

The radiators were completely closed during the field study, however, normally radiators are kept open. The comfort situation in the classrooms was mostly on the hot side even when the radiators were closed. It is shown that there is unnecessary energy consumption in these classrooms. It is suggested that planning for HVAC systems should be done separately for each room, and if not possible, the rooms should be classified as north and south.

It will be an economical and effective solution to use shading devices in the southern facade of classrooms with high transparency ratios (causing thermal discomfort) such as the existing classrooms studied. With the correct use of shading devices, solar control is provided and energy consumption is reduced while providing thermal comfort conditions during heating-cooling periods. In addition, with the correct use of shading elements, daylight is also used, which can reduce energy consumption.

This study is different from other studies since field studies were conducted in an educational building in the temperate humid climate. If integrated with other similar works, results and suggestions of this study can be exploited to design of transparent areas of existing or in design phase educational building. The results would be different for buildings located in different climates, in different directions and having different functions. The analysis must be made for each building separately in the design phase. It is necessary to determine the transparency ratios, depending on the function, by considering the thermal comfort as well as the visual and acoustic comfort at the design stage. More extensive studies can be carried out by using the method of this study and combining it with visual comfort. In this study, where the effect of transparency ratio on thermal comfort is determined, the awareness of architects and engineers on the subject are expected to increase.

\section{Acknowledgements}

This research did not receive any specific grant from funding agencies in the public, commercial, or not-for-profit sectors.

\section{Conflict of Interests}

The Authors declare no conflict of interest. 


\section{REFERENCES}

[1] J. Apte \& D. Arastech. Window-related Energy Consumption in the US Residential and Commercial Building Stock. Lawrence Berkeley National Laboratory (LBNL), Berkeley, CA, 2006. https://doi.org/10.2172/9287 62

[2] G. Evola, F. Gullo \& L. Marletta. The role of shading devices to improve thermal and visual comfort in existing glazed buildings, Energy Procedia, 134, 2017. 346-355. https://doi.org/10.1016/j.egypro.2017.09.543

[3] J. Jiang, D. Wang, Y. Liu, Y. Xo \& J. Liu. A study on pupils' learning performance and thermal comfort of primary schools in China. Building and Environment, 134, 102-113, 2018. https://doi.org/10.1016/j.buildenv.2018.02.036

[4] Z. Bakó-Biró, D.J. Clements-Croome, N. Kochhar, H.B. Awbi \& M.J. Williams. Ventilation rates in schools and pupils' performance. Building and Environment, 48, 215223, 2012. https://doi.org/10.1016/j.buildenv.2011.08.018

[5] J.M. Daisey, W.J. Angell \& M.G. Apte. Indoor air quality, ventilation and health symptoms in schools: An analysis of existing information. Indoor Air, 13, 53-64, 2003. https://doi.org/10.1034/j.1600-0668.2003.00153.x

[6] Yükseköğretim Kurulu (YÖK). 2018-2019 Öğretim Y1l Yükseköğretim İstatistikleri. Yükseköğretim Bilgi Yönetim Sistemi, 2020. [Turkish Higher Education Council (YOK). 2018-2019 Academic Year Higher Education Statistics. Higher education information management system, 2020.]

[7] M. Alwetaishi, M. Impact of glazing to wall ratio in various climatic regions: A case study. Journal of King Saud University - Engineering Sciences, 2017. https://doi.org/10. 1016/j.jksues.2017.03.001.

[8] A.R. Amaral, E. Rodrigues, A.R. Gaspar, \& A. Gomes. A thermal performance parametric study of window type, orientation, size and shadowing effect. Sustainable Cities and Society, 26, 456-465, 2016. https://doi.org/10.1016/j.sc s.2016.05.014

[9] T. Ashrafian \& N. Moazzen. The impact of glazing ratio and window configuration on occupants' comfort and energy demand: The case study of a school building in Eskisehir, Turkey. Sustainable Cities and Society, 47, 2019. https://doi.org/10.1016/j.scs.2019.101483

[10] H. Bernardo, C.H. Antunes, A. Gaspar, L.D. Pereira \& M Gameiro da Silva. An approach for energy performance and indoor climate assessment in a Portuguese school building. Sustainable Cities and Society, 30, 184-194, 2017. https://doi.org/10.1016/j.scs.2016.12.014

[11] Z.S. Zomorodian \& M. Tahsildoost. Assessment of window performance in classrooms by long term spatial comfort metrics. Energy and Buildings, 134, 80-93, 2017. https://doi.org/10.1016/j.enbuild.2016.10.018

[12] ANSI/ASHRAE Standard 55: 2017. Thermal Environmental Conditions for Human Occupancy. American Society of Heating, Refrigerating and Air-Conditioning Engineers, 2017.

[13] G. Gedik. Thermal Comfort Course Notes. Yildız Technical University- İstanbul, 2015.

[14] Testo 480-Digital Temperature and Humidity Meter. Multi-function VAC measuring instrument, Multi-function VAC measuring instrument. testo 480 - Cutting-edge technology for professionals, Product Brochures, 2019.

[15] BS EN ISO 7730: 2005. Ergonomics of the thermal environment - Analytical determination and interpretation of thermal comfort using calculation of the PMV and PPD indices and local thermal comfort criteria. International Standardization Organization, Britısh Standard, 2005.

[16] BS EN ISO 10551: 2019, Ergonomics of the physical environment - Subjective judgement scales for assessing physical environments. International Standardization Organization, Britısh Standard, 2019.

[17] F. Zoroğlu. Alışveriş merkezlerinin 1sıl konfor ve enerji tüketimi açısından değerlendirilmesi. Yüksek Lisans Tezi, Yıldız Teknik Üniversitesi [An evaluation of thermal comfort conditions and energy consumption of the shopping malls. Master Thesis, Y1ldı Technical University], Istanbul, 2017. 